\title{
CITRA MODERNITAS DALAM PEMBELAJARAN BAHASA DI MADRASAH ULUMUL QURAN
}

\author{
Cut Intan Meutia \\ IAIN Langsa \\ cut.tantia@gmail.com
}

\begin{abstract}
Abstrak
Penelitian ini bertujuan untuk melihat citra modernitas dalam pembelajaran bahasa Arab dan bahasa Inggris di pondok pesantren Madrasah Ulumul Quran. Penelitian ini dilakukan karena meskipun kedua bahasa asing (Arab dan Inggris) itu diajarkan secara seimbang namun para santri cenderung untuk mendalami salah satu bahasa asing itu. Adapun yang menjadi pembahasannya adalah bagaimana bahasa Arab dan Inggris menggambarkan identitas dan citra modernisasi dalam pembelajaran bahasa asing di kalangan santri di Madrasah Ulumul Quran di Langsa Adapun yang menjadi subjek penelitian ini adalah santri putra dan putri yang telah duduk di Madrasah Aliyah. Pemilihan subjek penelitian ini dengan menggunakan purposive sampling method karena santri yang duduk di kelas Aliyah telah lebih lama terekspose dengan kedua bahasa asing tersebut. Dari hasil penelitian, beberapa faktor yang menentukan kecenderungan memilih menggunakan salah satu bahasa, yaitu faktor lingkungan. Santri memilih untuk mendalami bahasa Arab karena tidak banyak yang mampu menggunakan bahasa tersebut. Selain itu teknologi juga memberikan warna baru terhadap pemilihan salah satu bahasa. Bagi santri Madrasah Ulumul Quran, keberadaan alumni juga mendorong para santri untuk mengeksplorasikan keahlian mereka dalam menggunakan bahasa yang lebih baik.
\end{abstract}

\section{Kata Kunci}

Modernitas, Bahasa Arab, Bahasa Inggris

\section{PENDAHULUAN}

Beberapa dekade yang lalu, dunia didominasi oleh monolingual language. Hal yang tidak dapat dipungkiri, sejarah mencatat mayoritas penduduk di dunia menggunakan monolingual language dalam berkomunikasi perkara yang ada. Persoalan suatu bangsa juga sangat berkaitan dengan penggunaan bahasa sebab sejarah terkandung dalam bahasa yang 
menggambarkan sebuah pemikiran (Al-Attas, 1990). Bahasa apapun yang digunakan sebagai alat komunikasi memiliki andil yang cukup besar dalam proses pembentukan identitas seseorang.

Berkah dari kemajuan abad 21 ini, banyak orang memiliki kebutuhan untuk berkomunikasi lebih dari satu bahasa. Oleh karena itu, penggunaan atau memahami satu bahasa perlahan berkurang. Ketertarikan orang ingin menguasai dipicu dengan perubahan trend yang terjadi di abad ke-21 melalui teknologi komunikasi. Hal ini pernah digambarkan oleh John Naisbit mengenai Megatrends 2000 di abad ke-21 sebagai era baru (Yasmadi, 2005).

Saat ini, pondok pesantren masih menjadi pilihan banyak orang khususnya pelajar yang ingin mendalami bahasa asing. Hal ini terlihat dari jumlah siswa yang ingin meneruskan belajar pada sekolah-sekolah yang berbasis boarding school. Keinginan untuk mengembangkan minat belajar bahasa asing di pondok pesantren bukan tanpa alasan. Pondok pesantren menawarkan interaksi dan komunikasi yang berkesinambungan dalam mengeksplorasi diri dalam belajar bahasa asing. Bahasa asing ini sangat mendominasi dalam kehidupan sehari-hari santriwan dan santriwati, mengingat bahasa Indonesia atau bahasa daerah dilarang digunakan dalam lingkungan pondok pesantren ini. Kendati menggunakan bahasa asing dalam kegiatan sehari-hari, penerapan program pengajaran bahasa asing di Madrasah Ulumul Quran ini tidak menggunakan metode English-immersion approach (dimana pelajar minoritas dikelompokan dalam kelas khusus dan dibina menggunakan bahasa Inggris dari sejak awal) (Papalia, Olds, \& Feldman, 2007). Pondok pesantren ini mengadopsi program bilingual education, dimana pelajar diajarkan dalam dua bahasa. Pengalaman penulis sendiri, bahasa Arab dan Inggris tidak saja dipelajari di ruang kelas, namun juga 
terintegrasi dalam kehidupan sehari-hari dalam lingkungan pondok pesantren tersebut. Seperti dalam bersosialisasi, bercengkrama, pentas seni, olah raga dan lain sebagainya.

Akan tetapi minat santri yang sedang mempelajari bahasa selama di pondok pesantren berbeda. Walaupun Bahasa Inggris dan bahasa Arab diajarkan secara seimbang di Madrasah Ulumul Quran Alue Pineung Langsa, akan tetapi tidak lantas para santri tertarik untuk mendalami kedua bahasa ini. Mengingat keberadaan Madrasah Ulumul Quran mendidik santrinya, salah satunya dengan mengajarkan bahasa Inggris dan Arab, karena itu diperlukan pengkajian tentang keberadaan bahasa Inggris dan bahasa Arab yang dimiliki oleh para santri yang sedang menimba ilmu di pondok pesantren tersebut. Untuk itulah peneliti tertarik untuk melakukan penelitian pada santri yang saat ini sedang menuntut ilmu di Madrasah Ulumul Quran Langsa.

\section{Modernitas dalam Teori}

Modernisasi sangat penting terutama bila dikaitkan dengan pengembangan ilmu pengetahuan dan teknologi, yang selalu membutuhkan alat yang tepat (bahasa) untuk menuangkan logika (Muslich, 2010). Modernitas merupakan gerakan perubahan yang bersifat progresif, kritis serta berkesadaran diri. Namun perlu adanya kontrol atas arah dari gerakan tersebut agar tidak bebas melenceng sesuai kehendak hati dari cita-cita semula. Sehingga ketika sudah ada kontrol dari gerakan tersebut, maka pandangan modernitas niscaya akan memberi perubahan yang lebih baik bagi kehidupan ini (Faizin, June 29, 2012).Modernisasi itu dipandang dari berbagai sudut dan karakternya. Dalam sudut pandang dunia barat, tidak ada batasan mutlak ekstensi makna dari modernisasi sedangkan dalam dunia Islam modernisasi tetap harus bersumber daripada ajaran Quran dan Hadist; akan 
tetapi, keduanya memiliki kebersamaan pola pandang bahwa modernisasi meninggalkan pola pikir tradisional menuju yang bersifat kritis dan rasional (Schorl, 1982).

Menurut Berger, Berger, \& Keliner (1902), hubungan antara bahasa dan sosial berlangsung secara dialektis dalam tiga komponen yaitu; eksternalisasi, objektivasi dan internalisasi. Eksternalisasi adalah pencurahan dunia, baik dalam aktivitas maupun mentalitas karena manusia dapat mengekspresikan dirinya dengan membangun dunianya (kenyataan yang diciptakan oleh manusia). Objektivasi adalah produk aktifitas baik fisik maupun mental suatu realitas seuai kefaktaan (masyarakat menjadi kenyataan sendiri yang berhadapan dengan manusia). Internalisasi, peresapan kembali realitas oleh manusia dan mentranformasikan ke dalam struktur-struktur dunia objektif pada kesadaran yang subjektif (kenyataan yang dibentuk masyarakat) (Nurudin,2008).

Bahasa berperan menjembatani perbedaan dalam masyarakat karena mampu merekatkan identitas sosial mayarakat dalam usahanya melakukan perubahan. Dengan berbahasa berarti hal ini tidak lepas dari keidentitas sosial diri dalam bermasyarakat yang diwarnai dengan sikap, prilaku, dan normanorma masyarakat yang ada. Jadi bahasa dan identitas sosial sangat terpengaruhi dan saling melengkapi. Yang jelas bahasa berperan penting dalam perubahan masyarakat.

Ada beberapa fungsi bahasa sebagai identitas diri antara lain, yaitu:

a. Bahasa menghubungkan antarberbagai komponen masyarakat. Dari sinilah individu dapat mengenalkan dirinya kepada khalayak masyararakat.

b. Bahasa dapat membuka peradaban. Adanya percampuran budaya, kesantunan diri, pengetahuan yang kompleks dalam mewujudkan diri 
yang beretika dan bernorma sesuai aturan yang ditetapkan dalam bermasyarkat.

c. Bahasa dapat manifestasi kontrol sosial dalam masyarakat. Mengatur bahasa sesuai norma, adat, cara, moral baik secara lisan, sikap atau nonverbal.

d. Bahasa berperan dalam membentuk sosialisasi nilai ke masyarakat. Dimana ada sebuah norma kesopanan disosialisasikan kepada generasi dengan contoh prilaku orangtua atau dengan pernyataan nasihat.

e. Berbahasa dengan orang lain berarti menunjukkan identitas atau jati dir kemanusianya. Seseorang akan diketahui identitas dirinya sebagai manusia karena menggunakan bahasa yang baik dan sopan sesuai kepribadian dirinya. Bahasa sebagai alat komunikasi menunjukkan jati diri atau identitas diri individu yang bersangkutan (Nurudin, 2008).

Di Indonesia (NAD) sendiri, bahasa asing khususnya bahasa Inggris mulai berkembang ketika jatuhnya rezim Soeharto pada tahun 1998. Pada masa Soeharto, warga negara Indonesia mewajibkan untuk bersekolah di sekolah pemerintah. Sedangkan akses untuk mengenyam pendidikan di sekolah International diperuntukkan bagi golongan expatriate saja (Coleman, 2011). Seiring dengan jatuhnya periode pemerintahan 32 tahun ini, permintaan akan sekolah International atau sekolah dengan basis berbahasa Inggris perlahan mulai banyak diminati; mengingat bahasa Inggris masuk ke seluruh aspek kehidupan. Dalam lingkungan pendidikan bahasa Inggris sekarang mulai dipelajari dari sekolah dasar kelas empat hingga sekolah menengah atas. 
Kendati sekolah program bilingual education tumbuh menjamur setelah kejatuhan masa 32 tahun pemerintahan Soeharto, tidak begitu halnya dengan pondok pesantren Madrasah Ulumul Quran di Langsa. Penggunaan bahasa asing sendiri di lingkungan pesantren telah mulai sejak pertama kali berdirinya pondok pesantren ini. Hal ini terlihat dari salah satu tujuan pendirian pondok pesantren ini. Bahasa Arab dan bahasa Inggris memiliki porsi yang sama dalam pengajaran dan pembelajaran bahasa di pondok pesantren Madrasah Ulumul Quran. Hal ini terlihat dari papan pamplex yang dipasangkan di lingkungan pondok pesantren dan juga jam belajar dari kedua bahasa asing tersebut.

Pertumbuhan bahasa asing lainnya adalah bahasa Arab. Bahasa Arab adalah bahasa ummat manusia yang dipilih oleh Allah untuk berkomunikasi dengan hamba-NYA Nabi Muhammad Saw yang diabadikan dalam Alquran dan hadis-hadis Nabi yang sampai kepada kita dan tersebar luas keseluruh penjuru bumi lantaran agama, ilmu pengetahuan, kebudayaan, sosial politik dan ekonomi (Shadry, 1980). Bahasa Arab sendiri adalah bahasa yang umum digunakan oleh sebagian penduduk di dunia yang berdomisili di belahan timur tengah dan beberapa negara di bagian benua Afrika dengan kadar dialek yang berbeda-beda.

Adalah Madrasah Ulumul Quran Langsa yang merupakan salah satu pondok pesantren di Langsa dan juga merupakan cikal bakal pertumbuhan pondok pesantren di Aceh. Madrasah Ulumul Quran ini membesarkan santrinya dengan menggunakan bahasa asing yaitu bahasa Arab dan Inggris sedangkan bahasa Aceh adalah menjadi bahasa Ibu mayoritas santri yang menuntut ilmu di pondok itu serta bahasa Indonesia adalah bahasa resmi yang digunakan dalam kehidupan sehari. Dalam kehidupan bersosialisasi di pondok pesantran ini, santri diharuskan menggunakan bahasa Arab dan 
Inggris untuk mencapai indikator keberhasilan proses pembelajaran yang sudah ditargetkan oleh pondok pesantran ini sebagai salah satu syarat kelulusan.

\section{Bahasa Arab, Bahasa Ibadah, Bahasa Akhirat}

Citra bahasa Arab di mata umat Islam memiliki ikatan emosional iman. Alasan bahasa Arab dipelajari oleh santri di Madrasah Ulumul Quran karena ada tuntutan untuk memahami bahasa yang digunakan dalam Quran. Hal ini terlihat dari paparan yang diungkapkan oleh santri itu sendiri. Bagi santri yang mempelajari bahasa Arab atau menjadi expert dalam menggunakan bahasa Arab dikarenakan ikatan emosional yang sangat kuat terlihat sejak kecil mereka belajar bahasa Arab. Hal ini dikarenakan didikan orangtua atau lingkungan dimana mereka tinggal lebih terekspos menggunakan bahasa Arab. Jadi semacam ada tuntutan atau kewajiban untuk memahami bahasa Arab ini.

Selain itu, bahasa Arab juga dipandang sebagai bahasa Alquran dan bahasa hadist. Al-quran dan hadist adalah pedoman hidup bagi umat Islam sehingga ada sebuah tuntutan untuk mempelajari bahasa Arab agar dapat memahami tuntutan tersebut. Lamb dan Coleman (2008) juga menyatakan bahwa:

Arabic, as the language of Islam, is used on a daily basis by an estimated 170 million Indonesians in their obligatory prayers and for a multitude of other religious functions. Individual competence in the language covers a a broad spectrum, from pure memorization of the prayers through to fluency in all skills (p. 192).

(Bahasa Arab adalah bahasa umat Islam yang digunakan lebih dari 170 juta jiwa penduduk Indonesia dalam melaksanakan ibadahnya sehari-hari dan juga untuk fungsi yang lain. Kemampuan seseorang dalam berbahasa Arab 
mencakup banyak hal mulai dari hafalan hingga keahlian berbahasa yang lain) (Lamb, \& Coleman, 2008). Dalam ibadah sehari-hari juga menggunakan bahasa Arab sehingga bahasa Arab juga dipandang sebagai bahasa ibadah yang harus dipelajari. Tidak saja sebagai pandangan hidup, bahasa Arab juga dipandang sebagai bahasa yang digunakan di surga kelak nantinya. Menurut penulis, mereka memahami bahwa bahasa Arab sebagai bahasa surga terkait dengan pola pikir atau anggapan dari orang banyak bahwa kelak bahasa itu yang akan digunakan di hari akhir kelak. Di sini identitas dipahami sebagai cara individu menentukan dan membatasi diri mereka sendiri. Identitas merupakan unsur hakiki struktur khusus kesadaran dan dengan demikian terhadapnya dapat dilakukan deskripsi fenomenologis (Berger, Berger, \& Keliner, 1992). Akibat pemahaman individu ini, secara tidak langsung akan mengarah kepada pemahaman kolektif mengapa bahasa Arab itu penting untuk dipelajari.

\section{Bahasa Inggris, Bahasa Dunia, Bahasa Universal}

Bahasa Inggris juga dikenali sebagai bahasa asing yang resmi di Indonesia setelah kemerdekaan Republik Indonesia. Apalagi pada masa itu dua bahasa asing yaitu Belanda dan Jepang mengalami penolakan sehingga memudahkan bahasa Inggris untuk tumbuh dengan leluasa di Indonesia. Meski perkembangan bahasa Inggris berjalan lambat khususnya pada era Soeharto, namun pasca kejatuhan Soeharto dari kursi pemerintahan pada Mai 1997 bahasa Inggris tumbuh bagaikan jamur di musim hujan. Bahasa asing sendiri, khususnya bahasa Inggris ini, digunakan untuk mendapatkan prestisekendati lawan berbicara bukanlah orang asing (Pusat Pembinaan dan Pengembangan Bahasa, 1978).

Bahasa Inggris sendiri mulai digunakan di Madrasah Ulumul Quran (MUQ) sebagai bahasa resmi komunikasi sehari-hari oleh santri sejak tahun 
1983 atau tepatnya awalnya berdirinya pondok pesantren tersebut. Ada beberapa alasan mengapa bahasa Arab dan Inggris ini yang kemudian hari banyak dipilih oleh para santri untuk mempelajari khususnya dalam interaksi mereka di Madrasah Ulumul Quran dan rencana masa depan yang ingin dicapai terkait dengan keberadaan bahasa asing ini.

\section{PEMBAHASAN}

\section{Modernitas Bahasa di Madrasah Ulumul Quran}

Lingkungan Santri memilih untuk mendalami bahasa Arab karena tidak banyak yang mampu menggunakan bahasa Arab. Jika bahasa asing lainnya khususnya bahasa Inggris bisa dipelajari di luar lingkungan pesantren tidak begitu dengan bahasa Arab. Bahasa ini terbatas dan tidak banyak yang dapat menggunakannya dengan baik. Keinginan santri mendalami bahasa Arab juga terkait dengan pilihan studi mereka yang ingin meneruskan cita-cita untuk belajar di tanah Arab. Tanah Arab adalah tanah impian bagi santri tersebut mengingat spirit keagamaan terkait dengan sejarah para utusan Allah (Nabi dan Rasul) yang berada di negeri Timur Tengah. Maka pemilihan bahasa sangat terkait dengan kesadaran dalam memahami persoalan agama. Selain itu, spirit belajar bahasa Arab ini juga sangat terlihat dengan banyaknya pesan petuah dari para ulama yang ternama. Keberadaan ulama tersebut juga memberikan ikat emosional yang besar walaupun secara pribadi mereka tidak mengenalinya. Selain itu, bagi santri yang dari kecil sudah akrab dengan pendidikan di diniyah sore hari, maka bahasa Arab telah mulai tumbuh sedari mereka kecil dan yang hanya ada dibenak mereka adalah belajar bahasa Arab perlu karena terkait dengan belajar mengaji seperti anak-anak muslim lainnya. 
Lain halnya dengan pengakuan santriwati yang lain bahwa keinginannya mempelajari bahasa Inggris karena lingkungan sekitarnya lebih memperkenalkan bahasa Inggris sebuah bahasa yang perlu didalami dan dikembangkan. Keinginan ini sangat terkait dengan yang disebut Erikson sebagai ego identity; hal ini terlihat dari remaja memiliki kecenderungan yang besar untuk mengikuti cara pandang orang lain (Djiwandono, 2006). Artinya para santri sebagaimana diceritakan di bab sebelumnya bahwa belajar bahasa terkait dengan orang-orang yang berada di sekitar mereka sehingga mempengaruhi keinginan untuk belajar bahasa. Tepatnya, mereka, para santri itu, telah melihat orang-orang yang sukses membelajar bahasa Inggris dan mencapai impiannya ke negara yang mereka tuju.

Hal ini terkait dengan cara berpikir pada teori Whorf (Whorfian Hyphotesis). Edward Sapir, guru Benjamin L. Whorf, menulis:

Bahasa adalah pandu realitas sosial. Walaupun bahasa biasanya tidak dianggap sebagai hal yang sangat diminati ilmuwan sosial, bahasa secara kuat mengkondisikan pikiran kita tentang masalah dan proses sosial. Manusia tidak hidup hanya dalam dunia objektif, tidak hanya dalam dunia kegiatan sosial seperti yang biasa dipahaminya, tetapi ia sangat ditentukan oleh bahasa tertentu yang menjadi medium pernyataan bagi masyarakatnya, tidak ada ada dua bahasa yang cukup sama untuk dianggap mewakili kenyataan sosial yang sama. Dunia tempat tinggal berbagai masyarakat, bukan semata-mata dunia yang sama dengan mereka yang berbeda (Rakhmad, 2007, p. 275).

Jadi pilihan bahasa sangat terkait dengan imaginasi di masa yang akan datang atau future imagination. Yang dimaksudkan dengan future imagination di sini adalah pilihan berbahasa sangat terkait dengan kemungkinan tawaran- 
tawaran untuk mencapai pilihan identitas di masa yang akan datang. Hanya saja yang perlu dipahami adalah pilihan santri berbahasa tersebut apakah murni karena keinginan sendiri atau pilihan emosi semata tanpa kejelasan. Pilihan emosi ini bisa saja akibat mengikuti arus karena menganggap bahasa adalah salah satu alat primer untuk mencapai kesuksesan dimasa yang akan datang.

Metode Keinginan santri untuk mendalami bahasa Inggris keterkait juga dengan kemampuan para pengajar bahasa Inggris yang lebih atraktif dalam mengajarkan bahasa Inggris. Hal ini memberikan daya tarik tersendiri bagi santri untuk mempelajari bahasa Inggris ini karena tidak seperti dengan bahasa Arab dalam belajar karena cenderung menggunakan hafalan dalam proses pembelajaran. Berbagai upaya dilakukan untuk membuat bahasa Inggris ini masuk ke semua lingkungan kehidupan. Meski pertama kali bahasa Inggris menyebar melalui ekspansi penjajahan yang dilakukan oleh penjajah Inggris, namun perlahan tapi pasti bahasa Inggris telah menjadi lingua franca. Tidak saja sampai disini, bahasa Inggris telah menciptakan selera pasar luar biasa. Semua pihak hampir mengacu pada metode pengajaran yang digunakan di dunia-dunia barat. Hal ini terlihat dari menyebarnya acara televisi yang menggunakan bahasa Inggris. (dalam hal ini bahasa Arab tidak terlihat dalam stasiun televisi nasional yang digunakan dalam menyampaikan berita atau bentuk lainnya, selebihnya malah menggunakan bahasa Mandarin). Selain itu, dalam konteks pondok pesantren Madrasah Ulumul Quran, penulis melihat begitu banyaknya jumlah buku yang atraktif dalam bahasa Inggris. Sayangnya penulis hanya melihat sedikit buku yang menggunakan bahasa Arab dalam menjelaskan isi buku tersebut.

Hal ini dapat dipastikan bahwa meskipun bahasa Inggris menyebar pertama kali melalui penjajahan, perlahan tapi pasti, negara-negara yang 
berbasis bahasa Inggris dalam hal ini Amerika, Australia dan Inggris terus mengadakan sejumlah pelatihan agar mudah untuk mengajarkan atau menggunakan buku-buku yang berbasis bahasa Inggris.

Lebih lanjut dalam hal metode pengajaran, penulis pernah melihat langsung ketika pondok pesantren ini kedatangan tamu yaitu native speaker dari negara Amerika. Datangnya orang asing ke pondok pesantren ini memberikan aura "kedekatan" untuk mempraktekan bahasa Inggris dengan native speaker tersebut. Di saat yang sama, kedekatan itu muncul karena orang asing tersebut lebih membuka diri untuk menerima hal yang baru. Ia dapat berbaur dengan leluasa dengan para santri meskipun hanya satu minggu berada di pondok pesantren ini. Kondisi ini tidak terlihat pada saat para syeikh yang dikirim dan mengajar di pondok pesantren selama bertahuntahun. Penulis menduga, mungkin kondisi ini terkait dengan budaya dari tempat para syaikh itu berada lebih tertutup sehingga kedekatan antara santri MUQ khususnya lelaki juga terasa lebih kaku apalagi dengan para santri putri yang hanya memiliki akses untuk bertemu dengan Syaikh tersebut di ruang kelas semata.

Dari hasil pengamatan akan ketertarikan santri untuk mempelajari bahasa asing ini sangat terkait dengan cara santri mendefinisikan diri mereka sendiri. Bagaimana seseorang menganggap diri mereka sendiri sangat bergantung bagaimana mereka mendeskripsikan sesuai dengan nilai sosial yang mereka alami sepanjang kehidupan mereka (Soeprapto, 2002).

Teknologi Di tahun 2000-an ketika internet merebak ke seluruh lingkungan kehidupan dan juga akses informasi begitu mudah tersebar oleh telepon genggam, informasi untuk melanjutkan sekolah ke jenjang yang lebih tinggi dan bervariasi semakin terbuka. Bila dulunya informasi tentang negara- 
negara barat tidak mudah dan terbuka untuk diakses, maka sekarang peluang santri untuk meneruskan pendidikan ke jenjang kuliah di sana terbuka dengan lebar. Kondisi ini menyebab santri-santri lebih mendominasi menggunakan bahasa Inggris atau lebih mendalami penggunaan bahasa Inggris. Penggunaan bahasa asing ini dimaksud dapat berupa secara aktif yang Meyerhoff (2006) nyatakan sebagai kemampuan memahami bahasa yang diiringi dengan kemampuan untuk memproduksikan serta menggunakan bahasa tersebut, maupun pasifyaitu kemampuan untuk memahami bahasa tersebut tidak dibarengi dengan kemampuan untuk berbicara (Meyerhoff, 2006).

Alumni Pada awal tahun 1990-an, alumni santri Madrasah Ulumul Quran banyak menggunakan bahasa Arab dalam berinteraksi sehari-hari di lingkungan pondok pesantren. Kondisi ini dimungkinkan karena informasi untuk melanjutkan sekolah ke jenjang yang lebih tinggi terbuka di negaranegara Islam semisalnya negara Sudan, Arab Saudi, Mesir, Malaysia dan lain sebagainya. Kesempatan bagi santri untuk meneruskan pendidikan mereka terbuka dengan lebar karena informasi untuk melanjutkan pendidikan ke universitas di negara tersebut begitu mudah didapat oleh santri. Informasi yang diterima tentu tidak dengan menggunakan internet melainkan berasal dari alumni sebelumnya yang pernah menikmati pendidikan di negara tersebut, bila mereka kembali ke tanah air maka akan menyempatkan diri untuk menyebarkan informasi tentang pendidikan di/dari negara-negara tersebut dan juga lembaga-lembaga yang terkait dengan keberadaan pondok pesantren, misalnya Departemen Agama. Dalam konteks ini, Departemen Agama bekerjasama dengan Universitas Al-Azhar untuk mengirim sejumlah alumni yang qualified dari berbagai pondok pesantren di Indonesia tidak terkecuali pondok pesantren Madrasah Ulumul Quran Langsa. Cerita para alumni yang lulus dari luar negeri juga memberikan 'bius' yang luarbiasa pada 
para santri. Mereka terobsesi untuk mengikuti jejak alumni dari Madrasah Ulumul Quran. Kondisi ini juga membuat keinginan santri untuk mendalami "bahasa impian" semakin kuat.

Modernisasi sangat penting terutama bila dikaitkan dengan pengembangan ilmu pengetahuan dan teknologi, yang selalu membutuhkan alat yang tepat (bahasa) untuk menuangkan logika (Muslich, 2010).Gidden menjelaskan lebih dalam mengenai makna modern ini. Ia mengatakan bahwa "refleksitas modernitas meluas hingga ke inti diri...kedirian menjadi sebuah refleksif'(Ritzer, \& Goodman, 2008). Hal ini dapat dipahami bahwa keinginan belajar bahasa asing secara tidak langsung perlahan dan bertahap telah mengarahkan seseorang untuk merefleksikan, membentuk hal yang baru yang mengalami perubahan itu.

Keberadaan alumni ini serta merta mengiring santri untuk memahami bahwa makna "modern" sesuai dengan keinginan masing-masing. Bagi para santri sayang senang dengan pelajaran bahasa Arab maka mereka mendefinisikan modern itu sangat berkaitan dengan negara pilihan masingmasing.Modernisasi itu dipandang dari berbagai sudut dan karakternya. Dalam sudut pandang dunia barat, tidak ada batasan mutlak ekstensi makna dari modernisasi sedangkan dalam dunia Islam modernisasi tetap harus bersumber daripada ajaran Quran dan Hadist; akan tetapi, keduanya memiliki kebersamaan pola pandang bahwa modernisasi meninggalkan pola pikir tradisional menuju yang bersifat kritis dan rasional (Schorl, 1982). Giddens lebih lanjut menjelaskan bahwa modernitas sangat terkait dengan persoalan risiko (Ritzer, \& Goodman, 2008). Adalah keberadaan alumni yang tampil menjelaskan keberadaan dimana mereka belajar juga memberikan resiko baru pada para santri untuk mendalami bahasa asing. Beck mengambarkan bahwa ilmuwan termasuk salah satu yang menurunkan resiko. Saya menyebutnya 
ilmuwan di sini dengan "alumni” karena Alumni adalah produk hasil belajar yang kelak atau telah menjadi ilmuwan. Lebih lanjut Beck mengatakan bahwa," Ilmu telah menjadi pelindung kontaminasi global terhadap penduduk dan sumber daya alam” (Ritzer, \& Goodman, 2008, p.563). Terkait dengan apa yang diungkapkan oleh Beck alumni menjadi salah satu sebab yang mengkontaminasi proses belajar bahasa yang memberikan citra modernitas di mata para santri.

Pandangan tentang modernitas tersebut menyangkut segala aspek dalam kehidupan manusia. Tidak terkecuali aspek kehidupan pendidikan, kebudayaan dan sosial. Kelemahan dari pandangan modernitas itu adalah, tidak adanya kontrol arah dari perubahan yang dilakukan. Sehingga arah dari perubahan yang terjadi bersifat bebas.

Setiap siswa mempunyai bahasa, gaya bahasa dan kekhasan bahasa masing-masing. Hal ini terkait dengan sebuah proses bagimana 'aku' memandang diri sendiri, bagaimana 'aku' mendefinisikan diri 'aku' sendiri..." (Soeprapto, 2006, p.206) Belajar bahasa Inggris ini sangat terkait dengan lifestyle seseorang. Bahasa Inggris seringkali diselipkan dalam penuturan bahasa nasional. Hal ini terkait dengan gaya hidup seseorang. Sang penutur bila menggunakan bahasa Inggris yang diselipkan dalam bahasa seshari-hari akan terlihat atau lebih berasa dengan "bigh class". Bahkan terkadang hingga lupa bahasa asli akibat pencampuran penggunaan bahasa asing ini khususnya bahasa Inggris.

Ketika dunia banyak melakukan transisi, maka bahasa Inggris masuk melalui semua celah yang ada terutama dalam teknologi komunikasi. Kondisi ini tentu saja menggambarkan keberadaan modernisasi yang terjadi dalam satu kelompok. Pengenalan mulanya zaman modern sendiri ditandai dengan terjadinya revolusi dimana otoritas gereja perlahan berkurang. Hal ini juga 
ditandai dengan zaman renaissance. Pada zaman ini perkembangan ilmu pengetahuan tidak lagi disandarkan oleh otoritas gereja (Muntasir, \& Munir, 2004).

\section{Citra Modernitas}

Proses modernisasi pesantren mulai dalam bidang pendidikan, khususnya pengajaran bahsa asing, ini juga mulai perlahan berkembang melalui media yang ada. Untuk tetap mengakomodir pengembangan pendidikan pesantren, pihak pesantren tetap menyediakan laboratorium bahasa yang digunakan untuk pengembangan kemampuan bahasa. Sejalan dengan pengadaan laboratorium tersebut, pondok pesantren juga menyediakan sejumlah kaset, CD yang berisikan muatan-muatan edukasi dalam pembelajaran bahasa asing. Selain itu, pesantren juga menyediakan televisi, komputer dan laptop yang tidak dapat digunakan secara bebas oleh santri. Penggunaan ini akan dimonitor dengan ketat akan penggunaan alatalat teknologi tersebut oleh para ustadz atau ustadzah di sana. Dengan maksud, penggunaan alat-alat canggih tersebut untuk pendidikan para santri namun tidak merusak moral santri tersebut. Media adalah alat yang paling ampuh dan halus untuk menyebarkan proses modernisasi ke pondok pesantren. Sampai sekarang ini masih banyak pondok pesantren yang tidak mengizinkan internet masuk ke lembaga ini. Mengingat pihak pondok mengalami kesulitan untuk memonitor penggunaan internet oleh para santri. Kendati para santri tidak memiliki akses untuk menggunakan internet, santri tersebut memiliki peluang untuk mengaksesnya ketika mereka pulang ke kampung halaman.

Kemudian modernisasi bahasa ini juga masuk melalui buku-buku yang digunakan oleh para santri di kalangan pesantren. Buku-buku ini didapat 
dari sumbangan dari berbagai donatur yang ada. Secara tidak langsung, santri belajar keberadaan negara-negara tempat dimana buku itu berasal. Dalam konteks bahasa asing, buku bahasa Inggris lebih banyak yang masuk ke perpustakaan mengingat sumbangan yang diterima banyak berupa buku-buku bahasa Inggris karena kemudahan untuk mendapatkan buku-buku tersebut. Pihak-pihak penyumbang tidak saja berasal dari negara dimana bahasa Inggris itu digunakan, akan tetapi buku-buku tersebut disumbang dari lembaga donatur dimana saja dan siapa saja.

Selain itu, santri-santri juga mulai mendapat izin untuk dikirimkan ke negara-negara barat dalam bentuk beasiswa. Meski Indonesia tidak termasuk negara yang dijajah oleh Inggris, akan tetapi gempuran akan pentingnya untuk mempelajari bahasa Inggris muncul dari segala aspek baik ekonomi, politik, hukum, budaya dan lain sebagainya. Hal ini tidak dapat dipandang sesuatu yang salah. Modernisasi bukan westernisasi ataupun sekularisasi. Semuanya itu tidak dapat disamakan. Modernisasi adalah perubahan cara hidup tradisional ke arah perkotaan. Namun tidak dapat dipungkiri bahwa perkembangan bahasa Inggris ini identik dengan linguistic imperialism.Robert (1997): menjelaskankan bahwa "Linguistic imperialism' is shorthand for a multitude of activities, ideologies and structural relationships. Linguistic imperialism takes place within an overarching structure of asymmetrical North/South relations, where language interlocks with other dimensions, cultural (particularly in education, science and the media), economic and political" (p.239).karena semua aspek dalam kehidupan tidak dapat dipisahkan oleh bahasa Inggris itu sendiri.

\section{PENUTUP}


Dari hasil penelitian, beberapa faktor yang menentukan kecenderungan memilih menggunakan salah satu bahasa, yaitu faktor lingkungan. Santri memilih untuk mendalami bahasa Arab karena tidak banyak yang mampu menggunakan bahasa tersebut. Selain itu teknologi juga memberikan warna baru terhadap pemilihan salah satu bahasa. Bagi santri Madrasah Ulumul Quran, keberadaan alumni juga mendorong para santri untuk mengeksplorasikan keahlian mereka dalam menggunakan bahasa yang lebih baik. Seiring dengan modernisasi pada bahasa dan munculnya semangat mempelajari bahasa Asing khususnya bahasa Inggris dan bahasa Arab, keberadaan bahasa lokal dalam hal ini bahasa Aceh dan bahasa Indonesia semakin memprihatinkan. Hal tersebut terjadi karena kita menganggap bahwa bahasa digunakan untuk menyusun gagasan karena pola-pola bahasa mencerminkan struktur gagasan. Sebenarnya, bukan suatu gagasan yang menentukan bahasa tetapi bahasa yang menentukan gagasan.

\section{DAFTAR PUSTAKA}

Al-Attas, S. M. N. (1990). Islam dalam sejarah dan kebudayaan Melayu. Bandung: Penerbit Mizan.

Atkinson, R. L., et al. (2009). Introduction to psychology. Jakarta: Erlangga.

Berger,P. L., Berger, B., \& Keliner, H. (1992). Pikiran Kembara: Modernisasi dan kesadaran manusia.Yogyakarta: Kanisius.

Coleman, H. (2011).Allocating resources for English: The case of Indonesia's English medium International Standard Schools. In Coleman, H. (Ed.), Dreams and realities: Developing countries and the English Language (pp.89-113).London: British Council Retrieved from www.teachingenglish.org.uk/transform/books/dreams-realitiesdeveloping-countries-english-language

Djiwandono,S. E. W. (2006). Psikologi pendidikan. Jakarta: Grasindo. 
Faiqoh. (2003). Pondok pesantren dan madrasah diniyah Pertumbuban dan perkembangannya. Jakarta: Departemen Agama RI, DIRJEN Kelembagaan Agama Islam.

Faizin, L. (2012, June 29). Modernitas dan pergeseran makna pendidikan di Indonesia. Retrieved from http://lukman-ffpsi09.web.unair.ac.id/artikel detail-49367-UmumModernitas $\% 20$ dan $\% 20$. Pergeseran $\% 20$ Makna $\% 20$ Pendidikan $\% 20$ di\%20Indonesia.html.,akses

Gultom, S. (2009, Maret 10). Reposisi pendidikan bahasa. Koran Waspada.

hoff,M. (2006). Introducing sociolinguistics. New York: Routledge.

Lamb, M.,\&Coleman, H. (2008). Literacy in English and transformation of self and society in post Soebarto Indonesia. Leeds: University of Leeds.

Mahmazar. (2010). Sebuab Thesis: Pembelajaran berbasis Kitab Kuning pada Lembaga Pendidikan Islam Non Formal di kecamatan Percut Sei Tuan kabupaten Deli Serdang. (Unpublished Thesis).

McMillan,J. H. (2008). Educational research: Fundamental for the Consumer.Boston: Pearson Inc.

Meyerhoff , M. (2006). Introducing sociolinguistics. New York: Routledge.

Muntasir,R., \&Munir, M.(2004). Filsafat ilmu. Yogyakarta: Pustaka Pelajar. hlm. 71 .

Muslich, M. (2010). Bahasa Indonesia pada era globalisasi. Jakarta: Bumi Aksara.

Nurudin. (2008). Sistem komunikasi Indonesia. Jakarta: RajaGrafindo Persada,

Papalia, D. E., Olds, S. W., \& Feldman, R. D. (2007). Human development. New York: McGraw - Hill.

Phillipson, R. (1997). Realities and myths of linguistic imperialism. Journal of Multilingual and Multicultural Development, 18(3), 239. Retrieved from http://http://lenguasvivas.org/campus/files/0 30/lingimperialism .pdf/ 
Pusat Pembinaan dan Pengembangan Bahasa. (1978). Depdikbud, kedudukan danfungsi Bahasa Minangkabau di Sumatra Barat. Jakarta: Depdikbud.

Rakhmad, J.(2007). Psikologi komunikasi.Bandung: Remaja Rosdakarya.

Ritzer, G., \& Douglas J. G.(2008). Teori sosiologi modern. Kencana Prenada Media Group.

Schorl, J.W. (1982). Modernisasi, pengantar sosiologi pembangunan negara-negara sedang berkembang.Jakarta: P'T. Gramedia.

Shadry, A. R. (1980). Nilai pengajaran bahasa Arab dan sejarah perkembangannya (1 st ed.). Bandung: Bina Cipta.

Sobur, A. (2003). Psikologi umum dalam lintasan sejarah. Bandung: Pustaka Setia.

Soeprapto, R. (2006). Interaksionisme simbolik; perspektif sosiologi modern. Malang: Averroes Press.

Soeprapto, R.(2002).Interaksionisme simbolik: Perspektif sosiologi modern. Malang: Averroes Press.

Tubbs, S. L., \& Moss,S. (2008). Human communication. Bandung: Remaja Rosdakarya.

Yasmadi. (2005). Modernisasi Pesantren: Kritik Nurcholish Madjid terhadap pendidikan Islam tradisional. Ciputat: Quantum Teaching.

Zacharias, N. T. (2010). Issues of Teyl in Indonesian and what parent can do about it. Indonesian Journal of English Language Teaching,6(2). Retrieved from http://ojs.atmajaya.ac.id/index.php/ijelt/article/view/168 